\title{
HLA-DRB3 wt Allele
}

National Cancer Institute

\section{Source}

National Cancer Institute. HLA-DRB3 wt Allele. NCI Thesaurus. Code C71260.

Human HLA-DRB3 wild-type allele is located in the vicinity of 6p21.3 and is approximately $13 \mathrm{~kb}$ in leng th. This allele, which encodes HLA class II histocompatibility antigen, DRB3 beta chain protein, is involved in the mediation of antigen presentation and stimulation of the immune response. The gene is polymorphic and typing is often performed to determine histocompatibility for hematopoietic stem cell transplantation. 